\title{
Heresia, doença, crime ou religião: o Espiritismo no discurso de médicos e cientistas sociais
}

\author{
Emerson Giumbelli
}

RESUMO: Desde a segunda metade do século XIX e até a década de 1940, as práticas e doutrinas espíritas mobilizaram o pensamento médico, num duplo empreendimento intelectual e de intervenção social. $\mathrm{O}$ artigo aborda vários textos elaborados, neste período, por médicos (tais como Nina Rodrigues e Leonídio Ribeiro), explorando como neles é definido e analisado o espiritismo, e localizando, entre as diversas épocas, continuidades e rupturas. Na década de 1930, o espiritismo e os cultos de possessão em geral começam a ser tratados por referência a categorias sociológicas e antropológicas, sinalizando uma transformação importante no seu estatuto (Arthur Ramos é um nome chave). No artigo, esta transição é problematizada a partir da análise da categoria "higiene mental", utilizada por intelectuais durante as décadas de 1920 e 1930 e associada às discussões sobre a constituição e destinos do Brasil enquanto nação.

PALAVRAS-CHAVE: medicina, espiritismo, religião, pensamento social brasileiro. 
Pretender falar de "espiritismo" no Brasil implica imediatamente colocar-se sobre um terreno minado de ambigüidades, imprecisões e, sobretudo, de polissemias. O termo foi, muito provavelmente, introduzido em nosso país pelos seguidores da doutrina referenciada à figura de Allan Kardec (1804-1869), pseudônimo de um pedagogo francês, e exposta em uma série de publicações inauguradas em 1857, com O Livro dos espíritos. Alguns anos depois, propagandistas das novas idéias chegavam ao Brasil pelos portos de Salvador e do Rio de Janeiro. Hoje, elas são assumidas por um número de pessoas que chega à casa dos milhões, nomeiam práticas de vários tipos, centradas em torno da "mediunidade", e mobilizam instituições de várias ordens, cujas células básicas são os centros espíritas ${ }^{1}$. A palavra "espiritismo", entretanto, não foi assumida apenas por esses adeptos, nem sempre foi utilizada para se referir especificamente a eles - apesar dos esforços e dos protestos recorrentes dos kardecistas. Podemos nos referir, em primeiro lugar, a um movimento de simplificação e generalização, que explica a aplicação de "espiritismo" a qualquer idéia ou prática que recorra à noção de "espíritos" e da sua intervenção no mundo cotidiano. Mais importantes, talvez, foram os movimentos de apropriação e ressemantização do termo, que deram origem a novos sistemas doutrinários e rituais, como é o caso do "espiritismo" do Centro Redentor, surgido na década de 1910 e depois rebatizado como Racionalismo Cristão, e do "espiritismo de Umbanda", institucionalizado desta forma no final da década de 1930 e depois proclamado como religião genuinamente brasileira ${ }^{2}$.

Falar de "espiritismo" é, então, sempre dizer muito - há coisas demais sob o termo - e dizer pouco - pois é difícil nos satisfazermos com tão pouca especificidade. Mas em um ponto, pelo menos, a categoria assume significado inequívoco e suficiente: na sua associação com práticas terapêuticas, como se "espiritismo" e "curandeirismo" participassem de um mesmo campo semântico e um mesmo território de 
realidade. Não é à toa que a menção a "espiritismo" comumente nos faz apelar para a imagem do indivíduo, que se diz inspirado por um "espírito", fazendo incisões, apenas com seus dedos ou uma simples faca, no corpo de outro indivíduo, inexplicavelmente anestesiado. E, de fato, o primeiro contato de muitas pessoas com centros kardecistas ou umbandistas ocorre em virtude da tentativa de resolução de algum problema físico ou de alguma aflição psicológica ou moral. Demanda que foi plenamente alimentada e satisfeita pelo mosaico de formas doutrinárias e rituais caracterizadas pela presença da mediunidade ou possessão e que se constituem, umas, em continuidade com as práticas arraigadas no que costumamos chamar catolicismo popular, outras, por afinidade com o que seus defensores afirmam ser uma medicina alternativa ${ }^{3}$.

Este texto, contudo, não pretende enfocar e discutir esse conjunto de práticas terapêuticas, que efetivamente existem e se constituem em expressões privilegiadas de certas concepções de realidade. A proposta é realizar, em relação ao espiritismo, uma operação semelhante à adotada por Said (1990) quanto ao Oriente - ou seja, tomá-lo como o produto de certas elaborações discursivas associadas a determinadas práticas de intervenção social. Mais especificamente, trata-se de abordar aqui alguns dos discursos formulados a partir do saber médico que tomam por objeto o espiritismo, seja para deslegitimá-lo como forma de "charlatanismo" ou "curandeirismo", seja para analisá-lo enquanto conjunto de doutrinas e práticas com certas implicações para seus adeptos e para o conjunto da sociedade. Veremos como, especialmente no período entre 1890 e 1940, o espiritismo torna-se alvo de preocupação para muitos médicos, que a partir de várias instituições e utilizando-se de vários meios vão formular teorias e acusações para explicá-lo e deslegitimá-lo. Neste período - e mesmo um pouco antes e um pouco depois dele - os argumentos médicos poderão ser encontrados em teses das faculdades de medicina, em debates nas suas enti- 
dades profissionais, em laudos médico-legais, em denúncias de funcionários sanitários; assumirão às vezes a forma de "campanhas contra o espiritismo" e serão constantemente encaminhados a autoridades policiais e governamentais; criarão polêmicas com aqueles que assumem sua identidade de espíritas, entre os quais se incluem muitos médicos; finalmente, serão defendidos, reapropriados e reinterpretados por criminalistas, advogados, juízes, jornalistas, padres e pastores interessados pela mesma questão.

Nesta incursão histórica pelos argumentos médicos, resolveu-se privilegiar aqueles que parecem ter sido os mais importantes, em virtude do impacto que tiveram em sua época e a lembrança que ainda hoje temos de seus autores. O objetivo básico é localizar e explorar continuidades e rupturas entre cada período analisado, demostrando como se relacionam com determinados modos de entendimento e de definição do espiritismo. E foi exatamente ao percorrer os caminhos traçados pelos discursos médicos que chegamos a elaborações e teorizações formuladas não mais a partir da medicina, mas em nome de uma ciência social interessada no estudo dos cultos de possessão no Brasil. Em outras palavras, não mais sobre fundamentos que remetiam essencialmente para o biológico, e sim para o social e o cultural. A década de 30 parece ter sido um momento chave para essa passagem e a idéia é exatamente problematizá-la, apontando para alguns de seus vários aspectos. Enfim, qual o contexto em que se faz essa passagem, em torno de que categorias ela ocorre e a que tipo de projetos de intervenção social ela está associada?

O resultado final é uma espécie de panorama histórico, que cobre especialmente o período entre a segunda metade do século passado e a década de 1960, sobre a variedade de estatutos conferidos ao "espiritismo", seja em nível ontológico (a verdade de seus fatos), seja na esfera legal (sua legitimidade como prática), seja ainda em termos topológicos (suas fronteiras em relação a outras práticas e idéias). Hoje 
parece evidente que se deva considerar o espiritismo uma "religião" como qualquer outra. Há algum tempo, contudo, ele foi diagnosticado como uma doença e perseguido como um crime; e, antes mesmo disso, negado por ser uma heresia. Mas é importante deixar claro que não se trata de um trajeto evolutivo, nem no sentido mais banal de algo necessário e teleológico, nem no sentido da depuração progressiva em um certo conjunto de fenômenos de todos os obstáculos epistemológicos que impediam uma apreciação mais adequada ou condizente com sua natureza. Trata-se, ao contrário, de mostrar como categorias distintas produziram realidades específicas, e que na utilização de tais categorias são igualmente definidas a natureza dos fundamentos legítimos de um discurso e os sujeitos competentes de sua enunciação. Assim, para que o "espiritismo" pudesse ser qualificado como uma religião, foi necessário que suas práticas e suas doutrinas tivessem se tornado equivalentes - vale dizer, designadas por um mesmo conceito - a de outras religiões e também que os cientistas sociais fossem reconhecidos como os intelectuais mais capacitados para a sua observação.

\section{Abominável heresia: o espírita como charlatão}

O que caracteriza a figura do "charlatão" no século XIX e qual o lugar dos "espíritas" nessa caracterização? Para responder a essa questão é necessário levar em conta as transformações por que passava a medicina no Brasil naquela época - em função das quais ela assumiria um papel fundamental na ordenação da sociedade. A partir das primeiras décadas do século passado, a atuação dos médicos e o saber por eles produzido orientaram-se em torno do que foi identificado como um projeto de medicalização da sociedade (Machado et al, 1978; Schwarcz, 1993; Montero, 1983). Por um lado, a medicina brasileira - seguindo de perto os modelos franceses - incorpora o meio urbano 
como alvo de reflexão e intervenção, meio social e natural diante do qual indivíduos e populações estavam igualmente ameaçados, física e moralmente. Os médicos tornam-se um misto de cientistas sociais, planejadores urbanos e analistas de instituições. Por outro lado, a medicina constitui-se como um apoio, científico e como tal autorizado, ao poder de Estado - oferecendo orientações sobre como ordenar as cidades e potencializar a vida de sua população.

Garantir o cultivo e a transmissão desse saber e atrelá-lo ao poder de Estado tornava-se, para a classe médica, uma prioridade. A principal das estratégias foi a criação das faculdades de medicina no Rio de Janeiro e na Bahia, regularizadas em 1832 por uma lei que restringia o exercício da medicina e da farmácia apenas aos indivíduos por aquelas formados. Enquanto as faculdades cumpriam a função de uniformizar o saber médico, a fiscalização caberia às Câmaras Municipais e, após 1850, a um órgão específico, ligado à administração sanitária. O resultado dessas estratégias foi a definição mais precisa de um antigo inimigo - o "charlatão": termo que designava uma série de práticas contra as quais os médicos julgavam ser seu dever combater e também o do Estado.

Vejamos como a questão aparece no discurso de um iminente membro da Academia Imperial de Medicina, dirigido em 1862 ao Imperador D.Pedro II (Moreira, 1862). Trata-se da posição da mais importante das associações médicas dirigida ao mais alto representante do Estado, em um período onde o "charlatanismo" é definido juridicamente como ilegal. Para o Dr. Nicoláo Moreira, os charlatães alastravamse por todos os cantos do país, e as pessoas que alimentavam seus "gabinetes" vinham de todas as camadas sociais. Dos vários processos citados como utilizados pelos charlatães, alguns denunciavam a sua imprudência (guias práticos colocados ao acesso de qualquer pessoa, venda de substâncias perigosas), outros a sua incompetência (indivíduos que, tendo algum conhecimento prático, agem como verdadei- 
ros médicos) e outros ainda pelo seu poder de ilusão (sonâmbulas e médiuns que prevêem o futuro e fazem diagnósticos; vendedores de elixires e panacéias universais). O que mais irrita o médico, entretanto, é o anúncio de remédios secretos, "que tornam o público juiz de sua própria moléstia e do medicamento que a deve curar", privandoo do diagnóstico e da prescrição médicos. Ou seja, o charlatão é especialmente condenável pelo fato de constituir um obstáculo entre o médico (com seu saber e sua prática oficiais) e a população ${ }^{4}$.

Outros aspectos da definição do "charlatão" aparecem quando analisamos as acusações feitas aos homeopatas nas décadas de 40 e 50 . A homeopatia chega ao Brasil através de Benoît Mure, um francês adepto das idéias do socialista Fourier, que se estabelece no Rio de Janeiro a partir de 1843 e aí funda o Instituto Homeopático do Brasil (cujos fins eram o ensino, a produção de remédios e a propaganda). A nova terapêutica logo ganha prestígio, disseminando-se pelas classes populares e ganhando adeptos entre a elite da Corte - desencadeando um enorme debate através de jornais de ampla circulação e de periódicos das associações médicas ${ }^{5}$. As acusações dos médicos ligados à Academia Imperial de Medicina apresentavam várias facetas, que apareciam estritamente vinculadas. Sucediam-se e intercalavam-se argumentos jurídicos (apenas o simples exercício da homeopatia era condenável, já que ilegal), científicos (a homeopatia era uma terapia inerte e nula; ou, ao contrário, seus medicamentos podiam envenenar os doentes), morais (homeopatas eram estrangeiros, de hábitos duvi$\operatorname{dosos}^{6}$ ) e políticos (os homeopatas eram perigosos, em função de sua ideologia socialista, para a ordem social e religiosa).

Interpretar essa heterogeneidade de critérios simplesmente como uma indicação de que seus autores não souberam manter o combate no terreno acadêmico ou profissional seria falsificar a questão. Mais interessante seria considerá-la como evidência de que a concepção de medicina com a qual lidavam os médicos em sua prática incorporava 
exigências de várias ordens. É assim que Dr. Nicoláo irá enfatizar: “A medicina não é somente o conhecimento empírico dos medicamentos nem a arte de ganhar dinheiro vendo doentes" (Moreira, 1862) - envolve, como ele explica, uma filosofia da arte de curar e uma moral. Daí ser também bastante heterogêneo e multifacetado, como demonstra o trabalho de Machado et al (1978), o conjunto de oposições acionado nas acusações aos charlatães: não era apenas a "ciência" contra a "credulidade", mas também a "religião" contra a "superstição", o "adiantado" contra o "primitivo", a postura "desinteressada" contra a "interessada", o método "racional" condizente com a "observação" versus o "irracional" e demasiado "empírico", a discrição de um saber oficial versus a publicidade de um saber privado. O charlatão é exatamente aquele indivíduo que desrespeita os códigos da medicina - não estando em discussão se o faz de modo premeditado ou não - em alguns dos seus vários aspectos. Como tal, até mesmo um médico formado nos bancos da faculdade pode ser considerado charlatão. Ele é, sempre e em todo caso, "um cultor da não ciência" (Machado et al, 1978).

No caso do espiritismo, a referência que lhe faz o Dr. Nicoláo reafirma os pontos mencionados. Sem discutir sua positividade enquanto fato, considera simplesmente uma insensatez que alguém possa dar atenção aos ruídos e batidas de simples mesas - forma pioneira de manifestação de "espíritos". Mas são razões mais fortes que o levam a condená-lo sem maiores discussões:

"Não admitindo o pecado original, negando o principio da espécie humana em Adão, sustentando que o inferno e o paraíso são apenas figuras, professando a reencarnação e a purificação contínua, roubandonos a perspectiva de uma vida futura que o catolicismo nos abre nas bordas do túmulo, a doutrina do espiritismo [...] além de irracional, é altamente irreligiosa." [Moreira, 1862:8]

O "espiritismo" não pode ser uma boa medicina porque está baseado em uma doutrina contrária à boa lógica e, sobretudo, à boa religião. 
O espiritismo é tema de discussão na Academia Imperial de Medicina em vários momentos da segunda metade do século XIX e a opinião dos médicos ganha espaço em alguns jornais, sempre relacionando espiritismo e charlatanismo, e caracterizando o espírita, "médium" ou não, como um perigo para a sociedade. Suas opiniões e reivindicações foram influentes o suficiente para favorecer a inclusão do "espiritismo", pelo primeiro código penal republicano (1890), entre os "crimes contra a saúde pública". O artigo 157 condenava sua prática, bem como a da "magia e seus sortilégios" e o uso "de talismãs e cartomancias" "para despertar sentimentos de ódio e amor, inculcar cura de moléstias curáveis ou incuráveis, enfim para fascinar e subjugar a credulidade pública". Ao lado dele, dois artigos intimamente associados: o artigo 156 punia a prática da medicina por indivíduos desprovidos de título acadêmico e o artigo 158 punia o exercício do "ofício assim denominado de curandeiro". Trata-se de um marco importante na trajetória que estamos aqui reconstruindo, pois esses dispositivos penais serão uma referência constante para todos os discursos formulados posteriormente sobre o "espiritismo" - inclusive aqueles ligados à medicina. O texto do Código Penal também é importante por transformar o que era apenas uma infração sanitária em um crime comum, sujeito à repressão policial. A partir dele, processos criminais serão instaurados e advogados e juízes estarão muito mais envolvidos na questão do que estavam antes ${ }^{7}$. Depois dessa pequena e necessária digressão sobre o campo jurídico, voltemos às formulações médicas sobre o "espiritismo", que tenderão a se tornar mais específicas e mais contundentes a partir da virada do século. Veremos como o ponto mais problematizado não será mais o conteúdo religiosamente hetedoroxo do "espiritismo" - acusação anacrônica no contexto de um Estado laicizado -, mas os prejuízos ocasionados aos indivíduos e à sociedade por suas práticas. 


\section{O espiritismo psicologizado: fisiologia ou patologia?}

Na última década do século XIX, o espiritismo será problematizado a partir de novos marcos, representados pelas categorias de "hipnose" e "sugestão". Entre 1888 e 1900, muitas teses versando sobre tais categorias são apresentadas nas Faculdades de Medicina do Rio de Janeiro e de Salvador e os mesmos assuntos passam a fazer parte de discussões em congressos de medicina. Ambas as categorias remetiam às trajetórias, concepções e compromissos da Psicologia européia do último terço do século XIX, especialmente ao movimento identificado sob a designação de "psicologia fisiológica". O principal significado de seu empreendimento residiu na reformulação da Psicologia na direção de uma ciência dos "fatos de consciência". A idéia fundamental era que a consciência e a vontade pairavam por sobre um conjunto de associações nervosas, cujo funcionamento obedecia a leis elementares que conferiam a muitas das atividades humanas um caráter reflexo e automático. Daí a possibilidade de "sugestionamentos" e "hipnotizações", cujos efeitos mais profundos residiam no poder de subversão ou comando da vontade humana. Como tais, essas noções serviram para interpretar fenômenos tão diversos quanto a possessão demoníaca na Idade Média, crimes sem explicação aparente e a própria vida em sociedade ${ }^{8}$. O interessante é que, a partir desse referencial comum, desenvolvemse contemporaneamente no Brasil apreensões sobre o espiritismo distintas o suficientes para poderem ser consideradas como concorrentes. Procurarei mostrar como esse distanciamento está relacionado às diferentes acepções com que foi utilizada a categoria "sugestão".

Uma primeira forma de entendimento pode ser percebida pela leitura de uma obra de Francisco Fajardo, intitulada Tratado de Hipnotismo (Fajardo, 1896) ${ }^{9}$. Neste livro, Fajardo está preocupado em definir os processos de "sugestão", descrever os estados fisiológicos que 
os caracterizam e os meios e métodos que a propiciam. Um número ainda maior de páginas é dedicado à comprovação de que a "sugestão" pode ser utilizada como método de cura para variados tipos de enfermidades. Um dos capítulos é sobre o "espiritismo", cujos "fenômenos" (a "telepatia", a "clarividência" e especialmente a "mediunidade") Fajardo considera que devam ser encarados sob a perspectiva dos conceitos que apresenta em sua obra. Para ele, o que os espíritas chamam de "mediunidade" equivaleria à manifestação, no indivíduo considerado "médium", de "um estado de consciência secundária ou inferior", produto do "automatismo cerebral" e de "sugestões" operadas por um terceiro ou pelo próprio indivíduo (Fajardo, 1896:306).

Fajardo, portanto, reconhece que as práticas associadas aos espíritas têm uma positividade, discordando contudo das causas que lhes são atribuídas: "A quase totalidade dos fenômenos espiritas se tornam explicáveis pela doutrina das variações e alterações da consciência" (:315). Tais fenômenos seriam reais não apenas porque não são necessariamente o produto de uma fraude, mas também por movimentarem forças eficazes que, para Fajardo, possuem propriedades terapêuticas. E é justamente por serem eficazes que essas práticas se tornam perigosas em mãos erradas. O livro contém um capítulo sobre as relações entre hipnose e criminalidade (:335-60), em que é afirmada, por exemplo, a possibilidade daquela técnica ser utilizada para facilitar violências sexuais. Os magnetizadores e as sociedades espíritas merecem uma menção especial. Os primeiros porque pertencem às camadas mais baixas da população e misturam fenômenos grosseiros às fraudes mais patéticas; as outras porque, sendo lideradas por "exploradores", provocam "algumas manifestações nervosas demais para o sócio, ou lançam-lhe alguns mil réis do bolso para fora”. Em razão disso, recomenda às autoridades que a hipnose seja reservada aos médicos, em se tratando de suas aplicações terapêuticas, e a indivíduos idôneos, em se tratando de fins experimentais. 
Contemporaneamente aos esforços de Fajardo, desenvolviam-se as reflexões de um outro médico - esse tornado pelo pensamento social brasileiro muito mais famoso: Raimundo Nina Rodrigues. Já foi bastante demonstrado como Nina Rodrigues teve uma atuação política e acadêmica que contribuiu decisivamente, de um lado, para a constituição de um campo institucional reservado à Medicina Legal (em seus entrecruzamentos com a Medicina, o Direito, a Psiquiatria e a Antropologia) e, de outro, para a problematização das relações raciais no Brasil $^{10}$. Entretanto, um dos aspectos certamente menos explorados nas análises dos escritos de Nina Rodrigues é a recorrência com que aí aparece a categoria de "sugestão" - e é exatamente em torno dela que pretendo situar as idéias do médico baiano dentro do quadro de elaborações discursivas sobre o espiritismo, localizando aí formulações com implicações bem distintas daquelas vistas na obra de Fajardo.

Apesar de ser a mesma categoria encontrada nas formulações de Fajardo, seu significado se modifica drasticamente. Para Fajardo, a "sugestão" remete para processos que eram essencialmente fisiológicos, sem qualquer conotação patológica, e que enfeixavam forças capazes de operar diversas curas. Todas as vezes que Nina Rodrigues recorrer ao conceito de "sugestão", este virá acompanhado de um outro, o de "predisposição", espécie de terreno mórbido sobre o qual um sugestionamento ganha condições de eficácia e que sempre subjaz a sua manifestação ${ }^{11}$. Ou seja, trata-se de um sentido que remete muito mais para a noção de doença mental, tal como definida pela Psiquiatria européia da segunda metade do século XIX a partir de conceitos como o de "degeneração". Através deles, a loucura passava a designar algo cujos sinais deveriam ser procurados no interior dos indivíduos, uma condição que os marca em seu corpo e em seus hábitos, em sua trajetória de vida e em sua ancestralidade. Características biológicas e padrões de comportamento e de moralidade apareceriam, com isso, cada vez mais associados em torno de condutas socialmen- 
te consideradas desviantes. O crime, por exemplo, poderá ser visto como um sintoma de alienação mental - o que colocaria novas questões para toda a lógica que orientava o sistema jurídico e penal ${ }^{12}$. Ora, um dos traços mais importantes dos esforços de Nina Rodrigues converge exatamente para isso: a atenção sobre as desigualdades humanas e a produção de uma "ciência da diferença" dedicada a relacionar necessária e permanentemente o social ao biológico, com a ajuda de postulados biodeterministas e evolucionistas.

Vejamos como esses pontos expressam-se na conhecida discussão sobre o "estado de possessão" nos candomblés baianos (Nina Rodrigues, 1935). Nina Rodrigues, antes de tudo, afasta a acusação recorrente de que tais fenômenos fossem necessariamente fruto de farsa ou simulação. A "possessão de santo" - em seus múltiplos graus, que variariam desde o "delírio prolongado" até a "simples excitação" derivaria, ao contrário, de "estados de sonambulismo provocado" (:109), envolvendo desdobramento e substituição de personalidade, além de alucinações e amnésia completa. A música, a dança, as palavras do pai-de-santo formariam um "sistema de impressão", comparáveis às técnicas dos mais "modernos hipnotizadores". Citando P.Janet (intelectual ligado à "psicologia fisiológica”), Nina Rodrigues afirma a relação do "sonambulismo provocado" com a "histeria" - sustentando, portanto, a base patológica das manifestações de possessão. $\mathrm{Ou}$ seja, para que a "hipnotização" efetivamente ocorresse e a "possessão" se desse, deveria haver um "terreno patológico" localizado na psicologia humana.

Netse caso, Nina Rodrigues relaciona a "histeria" a fatores que caracterizariam intrinsecamente os indivíduos da raça negra. Entretanto, em outra ocasião, ao comentar as práticas de uma "seita espírita" envolvida em uma "epidemia doméstica de loucura"13, deixa claro que as "predisposições" podiam estar associadas não apenas a características raciais, mas a vários outros sinais de pertinência cultural e social 
desqualificante. E embora ele confesse não ter tido jamais contato direto com práticas "espíritas", se isso acontecesse provavelmente confirmaria as considerações elaboradas a propósito dos candomblés baianos.

Comparadas às posições de Fajardo, as teorias de Nina Rodrigues guardavam, a um só tempo, parentesco e divergência. Por um lado, o movimento comum de negação do caráter necessariamente fraudulento das manifestações "mediúnicas" e a sua remissão a processos localizados na psicologia humana produzem uma "fenomenização" do espiritismo. Isso não apenas invalida a utilização generalizada do argumento da fraude, como também conduz a uma separação entre os "fenômenos" e as doutrinas (interpretações equivocadas) que, para seus praticantes, os explicam e justificam. Além disso, podemos dizer que esse critério tem o efeito de produzir uma autonomização daqueles fenômenos em relação, por exemplo, a dimensões (moral, religião, ideologia política) que podiam ser consideradas, como vimos antes, constitutivas da experiência médica. Nesse sentido, tanto Fajardo quanto Nina Rodrigues marcam uma ruptura em relação às concepções que abordamos na seção anterior. Por outro lado, Nina Rodrigues nos apresenta um dado inédito, condensado na idéia da patologização e psiquiatrização da "mediunidade", em decorrência do qual algo paradoxal se desenvolve: a patologização, ao mesmo tempo em que supõe uma delimitação de condições, sintomas, processos, etc. muito mais precisos em relação a outros fenômenos de ordem psicológica, remete imediatamente a determinadas situações e estatutos sociais. Nas teorias de Fajardo, psicologia e sociologia constituem dois domínios e momentos muito bem delimitados: o "espiritismo" movimenta forças eficazes e sua condenação não se faz em termos psicológicos, mas em função da utilização socialmente espúria que dele se faz. No caso de Nina Rodrigues, toda psicologia, por mais profunda que seja, desemboca sempre e necessariamente em uma sociologia. Lembremos que, se sua formação foi médica, suas preocupações estiveram sem- 
pre referidas à questão da nação brasileira, suas condições de formação e sua viabilidade, ainda que isso se manifestasse no tratamento de assuntos mais específicos - como os costumes e a religiosidade dos negros.

Finalmente, qual a posição de Nina Rodrigues diante de algo que, no livro de Fajardo, se apresentava inteiramente integrado aos conceitos utilizados para pensar os "fenômenos espíritas" - isto é, a questão terapêutica? Em $O$ animismo fetichista (Nina Rodrigues, 1935), ele desenvolve, com base em suas observações nos candomblés, uma extensa discussão sobre os "feitiços", entre os quais se incluíam, no lugar mais destacado, as práticas de cura africanas. $\mathrm{O}$ argumento ajuda a entender a singular posição de Nina Rodrigues quanto ao "curandeirismo". Ele procurava demonstrar, antes de tudo, que as práticas curativas comandadas pelos pais-de-santo dependiam, coerentemente, de concepções mágicas sobre as doenças, suas causas e o modo de combatê-las: "o feiticeiro destrói o que é produto de encantação". Isso, entretanto, não o impede de condená-las com base em um saber que considerava superior (em suas explicações e em sua eficácia), alertando inclusive para os prejuízos que poderiam advir para os indivíduos que se submetiam aos tratamentos mágicos. Nina Rodrigues comenta vários casos em que toma o cuidado de reinterpretar os diagnósticos ou os tratamentos segundo o saber médico acadêmico, demonstrando que mesmo quando o doente acabava curado, isto se dera por processos e condições totalmente ignoradas pelo curandeiro. Daí a posição política do médico baiano, comprometida ao mesmo tempo com a defesa da restrição do exercício da medicina aos diplomados (pois era preciso proteger a população) e com uma crítica do uso de métodos repressivos contra as práticas que ele mesmo condenava como "primitivas". Se tais práticas estavam enraizadas profundamente em um "sentimento religioso", não seria a força das leis e da polícia que iria arrancá-las do cotidiano de uma boa parte da população brasileira ${ }^{14}$. Isso não impedia, como vimos, que Nina Rodrigues encontrasse elementos patológicos entre as experiência mais características dessa "religião". 


\section{Entre a loucura e o crime: diagnóstico e punição do espiritismo}

O pensamento médico a respeito do espiritismo caminhará, nas primeiras décadas do século, em um sentido verdadeiramente radical. O tema que até então tinha sido tratado no meio de uma obra ou mesmo de passagem torna-se objeto de teses, artigos e livros inteiros. Em 1927, a Sociedade de Medicina e Cirurgia do Rio de Janeiro promove um "inquérito" sobre o "espiritismo", do qual participam 11 médicos, a maioria dos quais ligada a especialidades e instituições psiquiátricas e médico-legais ${ }^{15}$. Pelos seus resultados, percebe-se estar diante não mais apenas de práticas nocivas à saúde da população - afastada em virtude delas de um tratamento adequado para suas enfermidades - mas de algo diretamente associado ao surgimento de anomalias psíquicas em indivíduos sujeitos a sua ação. A julgarmos pela impressionante recorrência com que aparece, a idéia de que o "espiritismo" fosse um "fator de doença mental" passara a fazer parte do senso comum médico e psiquiátrico deste período. A história dera razão a Nina Rodrigues ${ }^{16}$.

A essa altura, tanto a Psiquiatria quanto a Medicina Legal já se mostravam bem consolidadas, tendo fortes raízes em aparatos médicos e jurídicos ligados ao Estado. No caso da primeira, isso ficava demonstrado pelo controle sobre os serviços públicos de assistência aos alienados mentais (incluindo o Hospital Nacional), por seu ensino na Faculdade de Medicina (desde 1886) e pela atuação de várias associações que representavam seus interesses (como a Liga Brasileira de Higiene Mental e a Sociedade Brasileira de Psiquiatria, Neurologia e Medicina Legal). A institucionalização da Medicina Legal no Brasil deve muito às idéias e ao trabalho de Nina Rodrigues, justificando que os principais espaços tenham sido ocupados por pessoas identificadas como seus seguidores ou simpatizantes. Embora constasse do currículo das faculdades de Medicina desde a fundação destas (1832), é no final do século, em virtude da aproximação com a 
Psiquiatria, que a Medicina Legal adquiriria uma maior especificidade enquanto saber e maior proeminência em suas implicações sociais. No âmbito dos aparatos policiais, gabinetes e serviços de medicina legal serão instaurados - no caso do Distrito Federal, antes mesmo da virada do século -, constituindo-se em antecedentes diretos dos institutos médico-legais da década de 30, período em que vemos se multiplicar o volume de pessoas, instituições, eventos, publicações e intervenções sociais relacionados a esse campo da Medicina. Aliás, Psiquiatria e Medicina Legal - elas mesmas produtos híbridos - constituíam espaços ocupados por agentes e saberes que se entrecruzavam. Seus protagonistas deviam possuir as qualidades da polivalência e da polifonia ${ }^{17}$.

Será a partir desses campos que o espiritismo será novamente problematizado e acusado nas décadas de 20 e 30 . O conteúdo desses posicionamentos demonstrava que informações estavam sendo acumuladas a partir de várias fontes: acadêmica, dispostas e sistematizadas em teses na faculdade de medicina; asilar, na medida em que os registros de antecedentes de pacientes com problemas mentais passaram a incorporar referências a "espiritismo"; policial, pois várias perícias médico-legais traçavam relações entre crimes, afecções mentais e à freqüência a práticas espíritas; e jurídica, a partir do momento em que os processos legais instaurados contra espíritas passavam a ser objeto de atenção e intervenção dos médicos. Em todos esses casos, notamos também um diálogo com teorias estrangeiras, especialmente as produzidas na França sobre "mediunidade", doença mental e criminalidade $^{18}$. Em determinados momentos, a discussão atingiu um tom de verdadeira polêmica, acompanhada pela imprensa, em que os médicos, a partir de alguma associação profissional, ao mesmo tempo em que dirigiam apelos ao poder público, tinham de rebater as posições dos defensores do espiritismo (entre os quais estavam alguns médicos) ${ }^{19}$.

Henrique Roxo e Xavier de Oliveira, dois psiquiatras ligados ao Hospital Nacional de Alienados, apresentavam estatísticas que colocavam o "espiritismo" como terceiro fator entre as causas de aliena- 
ção mental, logo atrás da sífilis e do alcoolismo, ao mesmo tempo em que discutiam entre si sobre as formas mais adequadas de se conceituar e tratar o que consideravam ser uma doença mental ${ }^{20}$. Entretanto, foi um livro publicado em 1931 que se transformou na principal referência em se tratando de concepções médicas sobre o espiritismo. Tratase de $O$ Espiritismo no Brasil, de Leonídio Ribeiro e Murillo de Campos, um "estudo clínico e médico-legal" do "espiritismo", aí definido como toda doutrina que postule a "... intervenção dos espíritos desencarnados dos mortos" para explicar um conjunto de fenômenos (Ribeiro e Campos, 1931:17). Murillo de Campos trabalhou, na década de 20, como psiquiatra nos serviços da Assistência a Alienados, tendo ligações com a Liga Brasileira de Higiene Mental. Já Leonídio Ribeiro constituiu-se, segundo Correa (1982), no personagem mais ativo de todo o grupo de intelectuais ligados à Medicina Legal no Brasil. Foi ele o principal promotor do inquérito sobre o "espiritismo" acima mencionado. Outro seguidor de Nina Rodrigues, Afrânio Peixoto, foi o prefaciador do livro, referendando suas idéias. Pela abrangência de suas discussões e pela importância que adquiriu como referência sobre o assunto, $O$ Espiritismo no Brasil pode ser analisado como exemplo privilegiado de um discurso que se desenvolveu a partir da associação de seus protagonistas com uma certa referência conceitual e um determinado espaço institucional. Três temas serão aqui destacados, aliás os mesmos que aparecem no inquérito da Sociedade de Medicina e Cirurgia: a explicação dos fenômenos ditos "espíritas", o "espiritismo" como fator de alienação mental e os danos que sua prática acarretariam para a saúde pública.

1. A primeira seção de $O$ Espiritismo no Brasil parte do desafio de "interpretar cientificamente" os fenômenos associados ao "espiritismo" sem recorrer ou chegar à noção de "espírito". Em relação ao que vimos anteriormente, há poucas novidades, que se concentram basicamente na extensão da discussão sobre as condições de comprovação 
do caráter positivo de práticas como "mediunidade", "clarividência", "telepatia", "materialização" e "levitação" e na utilização de teorias (como a Psicanálise) de formulação mais recente. No final, um resultado parecido: mesmo que algumas dessas práticas tivessem algum fundamento objetivo, este deveria ser buscado na dinâmica psíquica dos indivíduos, podendo-se recorrer, no caso da "mediunidade", para fatores como "sugestões", "dissociações psíquicas" e "afloramentos do subconsciente".

Novamente, portanto, produz-se uma "fenomenização" das práticas associadas ao "espiritismo". Entretanto, mesmo se Ribeiro e Campos reconhecem a positividade de vários fenômenos, não é enquanto "forças eficazes" que eles tendem a aparecer (como pensava Fajardo), mas manifestações do psiquismo individual facilitadas por uma postura de passividade estimulada pelo "espiritismo". Outro dado inédito origina-se de um esforço em dizer algo sobre o quê, a partir de uma operação de "fenomenização", converte-se em uma interpretação equivocada dos fatos: a doutrina "espírita". Mesmo reconhecendo a existência de modalidades diversas de "espiritismo", os autores definiram todas elas como uma forma moderna da "magia", tida como "um apelo para o sobrenatural" característico das "primeiras fases da evolução do espírito humano" (Ribeiro e Campos, 1931:20). Xavier de Oliveira (1931:18), citando Tylor, considera todas as formas de prática espírita como "modalidades da velha feitiçaria". O mais importante, então, não eram conteúdos doutrinários ou formas rituais, mas um julgamento epistemológico com base em uma oposição claramente evolucionista entre o científico-psicológico e o apelo ao sobrenatural.

2. As conclusões modificam-se de forma significativa quando se passa dessa apreensão mais ou menos abstrata dos "fenômenos espíritas" para uma análise a partir das condições concretas em que elas se realizam - ou seja, o ambiente das "sessões espíritas". Aí, encontram-se "muitos indivíduos cujo equilíbrio mental não se acomoda a 
tal ambiente de mistério, [...] predispostos hereditariamente às afecções mentaes". Trata-se de indivíduos "já psicóticos", que passam a incorporar "motivos espíritas" em seu quadro de sintomas; "débeis psíquicos", que procuram as "sessões espíritas" para fugir às dificuldades do cotidiano; os de constituição "esquizóide", para os quais o "espiritismo" é um pretexto para se fugir ao convívio social; finalmente, as "histéricas", que "espontaneamente se revelam médiuns e se prestam a exibições análogas às sonambúlicas” (Ribeiro e Campos, 1931: 634). Ribeiro e Campos referem-se, assim, à possibilidade de uma "mediunopathia" ou uma "mediunomania" que, ao contrário do que poderíamos pensar, não designaria uma entidade nosológica individualizada, mas uma série de manifestações - especialmente de caráter alucinatório e delirante - que têm como base uma "predisposição" que é anterior ao contato dos indivíduos com as práticas "espíritas". Assim, o correto seria falar em uma "loucura de colorido espírita", havendo inclusive a possibilidade de o indivíduo já ter desenvolvido uma doença mental e, ao procurar o "espiritismo", passar a incorporar "motivos espíritas" a sua enfermidade. Se por um lado o "espiritismo" pode concorrer apenas para uma "modelagem dos sintomas", há outros casos em que o contato com ele desencadeia uma perturbação que do contrário teria ficado como mera "predisposição". O "espiritismo" é perigoso exatamente porque pode ser o "fator desencadeador" da alienação mental.

Outro ponto importante refere-se ao fato de que essa "loucura de colorido espírita" apresenta uma progressão cujo modelo é o da possessão por uma força externa ao indivíduo. O seguinte trecho bem demonstra isso:

“... os indivíduos impressionáveis ficam abalados com os movimentos da mesa [...]. A emoção leva-os às conclusões mais levianas, às interpretações mais apressadas, [...] lembranças afloram como no sonho [...]. E, como nesses indivíduos, a capacidade crítica está diminuída por motivo da emoção, o sonho toma as proporções de um delírio alu- 
cinatório, no qual a personalidade, o eu se encontra em desagregação. Os exercícios de mediunidade acabam por torná-los loucos que crêem pensar, falar, gesticular, escrever, andar, contra a própria vontade, e em obediência à vontade do 'espirito' que passou a residir neles." [Ribeiro e Campos, 1931:66]

O que começaria com uma simples "impressão" ou "sugestão", evoluiria até tomar a forma de "alucinações", desembocando, enfim, em uma "mania". O personagem, identificado ao "espiritismo", que mais se adapta a esse modelo é evidentemente o "médium", imaginado aqui como alguém completamente dominado pelos "delírios" e "alucinações" de sua mente.

Essa patologização/psiquiatrização do "médium" está inserida em toda uma cena ritual em que, como em Nina Rodrigues, todos os elementos são interpretados pelo seu poder de sugestibilidade e pela impressão que podem causar nos presentes. Além disso, há outros dois personagens: o diretor da "sessão espírita" (ou o chefe do "centro") e a assistência. Mantém-se a imagem tipicamente aplicada aos consultórios ou espetáculos de sonambulismo, concebida segundo a economia das relações que distinguem e vinculam seus três elementos. Em um vértice, o diretor da sessão, que se relaciona com o segundo vértice - o "médium", um doente mental por definição - através de uma série de artifícios eficazes (música, exortações verbais, etc.) que o incitam ao transe; finalmente, no terceiro vértice, a assistência, uma espécie de microcosmos da sociedade brasileira em que predominam pessoas "ignorantes", "analfabetas", de "inteligência inferior" - a um só tempo sujeitas às influências psiquicamente deletérias proporcionadas pelo ambiente da "sessão" e exploradas pecuniariamente pelo diretor do "centro"21. Ou seja, o diagnóstico médico articula-se de forma absolutamente necessária com uma análise "sociológica" e se são sociais e morais os critérios que servem para identificar os freqüentadores das "sessões espíritas", a distância que a princípio separa a assistência do "médium" pode ser facilmente transposta. Portanto, 
embora a psiquiatrização tenha como objeto privilegiado o "médium", não se limita a ele: estão ameaçados todos os freqüentadores das práticas "espíritas", cuja susceptibilidade não é definida por critérios simplesmente biológicos, mas por algo que está entre seu psiquismo e suas condições sócio-culturais.

A possibilidade do "espiritismo" propiciar anomalias mentais estava, então, claramente estabelecida. Dos onze médicos que participam do inquérito da Sociedade de Medicina e Cirurgia, nove deles se manifestaram afirmativamente sobre essa possibilidade. As categorias "predisposição", "sugestão", "alucinação" e "delírio" são as mais recorrentes nas formulações médicas desse período a respeito do espiritismo. Embora essas categorias só pudessem ser mobilizadas a partir de espaços muito específicos - acadêmicos, asilares e policiais -, a forma como eram utilizadas por esses médicos ameaçava abranger boa parte da sociedade brasileira.

3. Haveria relação entre práticas espíritas e criminalidade? Certamente, dado que era possível ocorrerem casos em que indivíduos, inspirados por "espíritos", cometiam crimes até hediondos. Mas o que mais preocupava os médicos eram os prejuízos que as práticas "espíritas" poderiam trazer para a saúde pública a partir do momento em que se constituíam como terapêuticas. A medicina dos "espíritas" era condenável porque colocava pacientes sob a responsabilidade de pessoas sem competência para tratá-las, ou porque impedia a intervenção competente dos médicos, ou ainda porque podia ser diretamente prejudicial, agravando uma enfermidade. Ou seja, a eficácia dessa medicina é terminantemente negada; ou melhor, não é nem mesmo objeto de discussão. Tendo como pressuposto a inexistência nela de qualquer virtude terapêutica, Ribeiro e Campos apontam como raiz do problema, de um lado, a "ignorância" e o "misticismo" do povo e, de outro, a falta de repressão por parte das autoridades competentes. A partir disso, tomam inclusive a liberdade de voltar o próprio discurso 
legal contra juristas e advogados, examinando processos criminais para lamentar e criticar as decisões dos juízes.

A essa altura, podemos formular a pergunta: como querer responsabilizar criminalmente indivíduos a quem se procurou imputar um diagnóstico de insanidade mental? Para respondê-la, apresentemos as medidas propostas por Ribeiro e Campos visando a repressão ao "espiritismo". Tratava-se de uma "campanha de higiene mental", endossada por vários dos médicos que participaram do inquérito da Sociedade de Medicina e Cirurgia, cujo plano consistia em impedir que anúncios e reclamos de centros espíritas aparecessem nos jornais e em mobilizar as autoridades policiais e sanitárias em vista de uma fiscalização ostensiva de todos os lugares de cultos, fechando "os mais perigosos", prendendo seus responsáveis e entregando os "médiuns" à observação de psiquiatras (Ribeiro e Campos, 1931:135). Percebemos que, nas soluções propostas para reduzir os perigos do "espiritismo", articulavam-se, nos argumentos médicos, discursos distintos. Nesse caso, é esclarecedor que nos remetamos novamente à tríade de que se compõem as "sessões espíritas", pois a cada um de seus elementos era aplicada uma lógica e atribuído um destino diferenciados. O "médium" personificava o estágio final de uma doença que em sua evolução comprometia a capacidade crítica e as forças volitivas do indivíduo, estando a inteligibilidade de seus atos sujeita a regras que só a Psiquiatria poderia desvendar. O diretor do "centro" personificava o explorador, um "magnetizador de sonâmbulas" que, por astúcia ou por ignorância, transgredia leis e, por isso, merecia os rigores do Código Penal. Aos indivíduos da assistência, prisioneiros de sua ignorância e incultura, nada mais indicado do que o esclarecimento e o encaminhamento para a verdadeira e eficaz medicina.

Desse modo, ao estar associado ao mesmo tempo a um "fator de alienação mental" e a uma "indústria organizada para explorar a credulidade pública", o "espiritismo" podia ser enquadrado ora como 
doença, ora como crime. Lembremos, por fim, que o sinal mais característico dessa "indústria" seria o "charlatanismo", definido pelos médicos simplesmente enquanto o exercício ilegal (sem formação acadêmica) da medicina - nem algo eficaz, como insinuava Fajardo, nem questão de "sentimento religioso", como deixara entrever Nina Rodrigues. Segundo as formulações dos médicos nas décadas de 20 e 30, o espiritismo, em virtude da natureza e das implicações de suas práticas, devia constar das preocupações de autoridades sanitárias e policiais e não há como separar seus diagnósticos psiquiatrizantes construídos e aplicados em instituições asilares - dos esforços políticos visando o combate e regularização daquelas práticas.

\section{Um outro discurso: o espiritismo como objeto sociológico e antropológico}

Uma forma de interpretar a história do pensamento social brasileiro é tomar exatamente os anos 30 como uma ruptura no sentido da introdução de uma nova categoria - "cultura" - que viria em substituição aos argumentos racistas e biologicistas. Assim, de um lado, Gilberto Freyre e sua formação boasiana; de outro, a extensa linhagem de intelectuais que se dedicaram especificamente ao estudo das "religiões negras", linhagem que começaria com Arthur Ramos e iria, no mínimo, até Roger Bastide, passando por Edison Carneiro, René Ribeiro, Herskovitz e seus alunos (para ficar apenas nos autores mais clássi$\cos$ ). A ruptura coincide com a institucionalização das "ciências sociais" no Brasil e poderia ser apresentada inclusive como o principal sintoma de que assuntos colocados anteriormente sob a alçada da Medicina passavam a ostentar o estatuto de "sociais" e "culturais". A discussão que aqui começa e segue até o final do artigo tem exatamente por objetivo contribuir com elementos que consigam complexificar a apresentação dessa transição. Para isso, serão privilegiados os textos 
de Arthur Ramos e Roger Bastide, por se tratarem de personagens ilustres dessa história que se mostraram preocupados com o "espiritismo". Tudo o que foi dito anteriormente a respeito do pensamento médico é fundamental, pois procurar-se-á demonstrar que os temas dos quais tratamos continuam vivos na obra destes autores, constituindo um debate no decorrer do qual se redefine o estatuto de várias práticas religiosas, entre elas o espiritismo.

Arthur Ramos tivera formação médica. Confessa mesmo que foi atraído para "a questão do Negro" - à qual dedicaria toda a sua atividade intelectual - a partir de uma experiência profissional em Salvador como médico-legista do Instituto que levava o nome de seu inspirador (Nina Rodrigues). Por outro lado, procura legitimar seu esforço de pesquisa a partir do que considerava uma ruptura em relação ao mesmo Nina Rodrigues: as produções culturais dos negros não obedeciam a determinantes antropológico-raciais, mas expressavam uma forma de pensamento "mágica" e "pré-lógica" (segundo os termos de Levy-Bruhl), "narcísica" e "involuída" (segundo as teorias psicanalíticas), encontrável em qualquer "grupo social atrasado em cultura" (Ramos, 1940 e 1946) ${ }^{22}$.

A importância disso se revelaria, por exemplo, nas teorizações de Arthur Ramos sobre os "fenômenos de possessão", que incluem os "estados de santo" dos candomblés ou as "manifestações de espírito" de outros cultos (Ramos, 1940). Debatendo, de um lado, com uma série de autores estrangeiros (franceses e alemães) e, de outro, com Nina Rodrigues, ele nega que se possa reduzir a "possessão" a uma "manifestação histérica". Os fenômenos que a caracterizam - "dissociação psíquica", "automatismo", "delírios", "alucinações" - são perturbações que poderiam "sobrevir em vários estados mórbidos e até psicológicos". Assim, embora envolva uma série de alterações patológicas da consciência, a possessão não expressaria uma "loucura espírita". A diferença em relação às teorias psiquiátricas que vimos no 
item anterior reside no fato de Arthur Ramos encarar esses fenômenos não como desencadeadores de verdadeiras enfermidades em indivíduos "predispostos" (envolvendo nisso algum fundamento biológico ou mesmo hereditário), mas simplesmente como um estado, algo momentâneo, paroxístico e transitório. Sua conclusão é de que as perturbações ocorridas durante os estados de possessão devem ser associadas a mecanismos mentais (aglutinação de imagens, simbolismos) e físicos (catalepsia e/ou convulsões) de ordem "ancestral", "primitiva". Ou seja, até mesmo a manifestação de fenômenos mórbidos tem por base processos que remetem a uma condição "mental" (a um só tempo psicológica e cultural) e não a uma disposição biológica ou hereditária.

Outra dimensão em que poderíamos sentir uma crítica a visões estritamente medicalistas é na discussão sobre o "curandeirismo". Em um trabalho apresentado ao I Congresso Médico Sindicalista, Arthur Ramos (1931), depois de criticar a doutrina impressa nos tratados de Medicina Legal, opera uma distinção entre "curandeirismo" e "charlatanismo": o primeiro designaria uma transgressão voluntária e consciente, por parte de um médico, de seu código de classe, visando uma maior clientela, mais proventos pecuniários, etc.; já o segundo é sempre o produto de indivíduos incultos, saídos das "classes inferiores da sociedade", que agem informados por "concepções mágicas", as quais fazem da doença e de seu tratamento algo "místico". O "curandeirismo", portanto, envolve uma mentalidade, uma psicologia e uma cultura diferenciais, dentro das quais ganha sentido. Arthur Ramos não aprova essas práticas, mas não perde tempo em refutá-las segundo um critério que seria mais científico. De Nina Rodrigues, ele reteve exatamente a idéia que havia sido desprezada por Ribeiro e Campos, enfatizando o que chamaríamos de conteúdo cultural de qualquer medicina religiosa.

Sua principal preocupação, na verdade, era como resgatar os grupos sociais dessa cultura, fazendo-os compartilhar dos benefícios de 
uma ação civilizatória. $O$ Negro brasileiro foi escrito com finalidades definidas como "higiênicas e educacionais"; oferecia um conhecimento das "modalidades do pensamento 'primitivo', para corrigilo, elevando-o a etapas mais adiantadas" em que os elementos "pré-lógicos" tivessem sido substituídos por outros mais "racionais" e "menos contaminados por dimensões afetivas" (Ramos, 1940). A solução preconizada para resolver o problema do "curandeirismo" - que dispensa a repressão dos policiais e os cuidados dos médicos - valeria para boa parte da população:

"um trabalho lento e tenaz de educação do meio, no esforço para a consecução de tipos mais adiantados de mentalidade [...]. É o combate decisivo da cultura contra a superstição, do justo e do racional contra o logro místico e a abusão fetichista." [Ramos, 1931:980] ${ }^{23}$

A mesma preocupação aparece quando Arthur Ramos trata do "espiritismo", algo que só pode ser entendido a partir de um outro grande desafio formulado por sua obra: explicar as razões pelas quais "as culturas negras não se conservaram no estado original" quando foram transportadas da África para o Brasil (Ramos, 1940 e 1946). Procurando dar respostas a essas questões, analisará a mitologia, a liturgia, as práticas mágicas e a contribuição oferecida por elementos das religiões africanas ao "folclore" nacional segundo as várias tradições encontradas no Brasil, que ele divide basicamente em duas - a iorubana e a banto. Em comparação com a tradição iorubana, a banto é considerada menos evoluída e mais simples pela sua mitologia e, sobretudo, mais degradada em relação a suas origens. A questão do "sincretismo" - válida para o conjunto da herança africana - aplica-se, portanto, especialmente para os bantos, cujas formas religiosas estão sempre permeadas por elementos de outras tradições.

É aí que Arthur Ramos encontra um lugar para o "espiritismo". Para ele, a "macumba carioca" seria, ao mesmo tempo, a modalidade religiosa mais identificada com a herança banto e o produto da incorpo- 
ração de elementos do catolicismo, do "espiritismo" e das culturas iorubanas. Em relação ao "espiritismo", isso ficava evidente na terminologia adotada pelas "macumbas" ("pai de mesa", "médiuns e médias", "centros"), o que na verdade expressava uma semelhança em um nível mais básico: na religião banto, como no "espiritismo" e distintamente dos iorubanos, existe um "verdadeiro culto dos antepassados e dos espíritos" (Ramos, 1940:110). E, apesar desse terreno comum, o que mais preocupava Arthur Ramos eram exatamente as influências do "espiritismo" - um termo a que nunca atribuiu uma definição categórica - sobre as formas de religiosidade originalmente africanas:

"Por influência cada vez maior do espiritismo, as macumbas de procedência bantu têm-se transformado rapidamente. Em muitas, já existe pouca diferença das mesas dos consultórios de baixo espiritismo das camadas atrasadas da população carioca... Por isso, as macumbas cedem pouco a pouco o lugar dos consultórios do 'Pai Joaquim' e de quantos videntes e conselheiros pululam pelos vários centros da população[...]." [Ramos, 1946:340]

Neste trecho, notamos a utilização de outra expressão - "baixo espiritismo" - que vai aparecer sempre relacionada à realização de alguma prática curativa com base nos conselhos de "espíritos" de várias origens. Arthur Ramos não consegue esconder sua condenação dessas práticas, associando-as mesmo a um processo de degradação das heranças africanas:

"Os pais e mães de terreiro ultrapassaram suas funções [sacerdotais] e tornaram-se conselheiros, videntes, cartomantes, etc., junto a que corre toda a corte de desenganados e infelizes a pedir conselhos e soluções para os múltiplos problemas amorosos e econômicos de sua vida." [Ramos, 1940:140] ${ }^{24}$

Enquanto médico e contemporâneo de figuras como Leonídio Ribeiro, Arthur Ramos bem poderia ter endossado suas reivindicações por medidas repressivas sobre "macumbas" e "centros de baixo espi- 
ritismo" espalhados pelo Rio de Janeiro. Preferiu, como vimos, sugerir o caminho "lento" da "educação", um caminho oportuno, aliás, para quaisquer "aglomerações atrasadas em cultura" (Ramos, 1940). Percebemos, contudo, como a introdução do conceito de "cultura", embora implique significativas transformações no nível das soluções, não se choca com um diagnóstico, no nível dos problemas, que destaca exatamente o que há de "atrasado" e de "irracional" nas práticas de determinados grupos sociais. É curioso, então, que mesmo a solução tenha sido designada tanto por Arthur Ramos quanto por Leonídio Ribeiro pela mesma expressão: "higiene mental". É em torno dessa categoria que se tecerão as considerações finais deste artigo.

Antes disso, contudo, passemos rapidamente pela obra do sociólogo francês Roger Bastide - que dispensa qualquer apresentação - procurando problematizar seus esforços, ao tratar das religiões africanas, de submeter a possessão a uma análise que desse conta de sua função no interior de um sistema de crenças e rituais: "o transe não se pode explicar simplesmente recorrendo-se a dados psicopatológicos. Ele de fato constitui um traço cultural, normal e obrigatório nas civilizações negras" (Bastide, 1971:516). Em outra ocasião, teve o cuidado de refutar várias das acusações que viemos analisando até aqui, negando que o "espiritismo" desempenhasse qualquer papel no desencadeamento de enfermidades mentais (Bastide, 1967). Em vista disso, parece interessante mostrar como o tema da psiquiatrização não está completamente ausente em suas idéias, e que sua permanência articula-se a uma nova forma de considerar os fenômenos religiosos dos quais Bastide pretendia dar conta.

A mitologia e a liturgia associadas ao "candomblé" representavam para Bastide a forma mais fiel pela qual a África estaria preservada no Brasil. Obrigados a se tornarem escravos e tendo sua organização social destruída, a cosmologia e as práticas que estão na base do candomblé atual teriam sido as responsáveis pela recriação das formas de 
solidariedade social que garantiram a adaptação do negro à nova situação. Como algo constituído e reproduzido coletivamente, o candomblé era capaz de fornecer as condições que tornavam suas cerimônias verdadeiros "dramas litúrgicos". Ou seja, o transe adquiria um caráter organizado e controlado pelo grupo, em que cada cavalo/médium desempenhava os papéis designados por uma tradição mítica bem estabelecida. No caso da "macumba urbana", as coisas se passavam diferentemente. Ela é o produto de uma reação frágil frente a uma situação de desagregação social proporcionada pelas condições de urbanização e industrialização no Brasil - que a princípio excluíram os descendentes de escravos do mercado formal de trabalho. Do ponto de vista religioso, ela teria se constituído a partir da progressiva assimilação, por parte da "cabula banto", de elementos iorubanos, católicos e espíritas - a ponto de não ter mais qualquer estabilidade dogmática e estar entregue às invenções de seus protagonistas. Por fim, seus freqüentadores não possuiriam nada em comum senão o baixo status social. É em função desse conjunto de coisas que suas festas serão um "misto de africanismos, de baixo espiritismo e de magia", um pouco espetáculo degradador de autênticas tradições africanas, um pouco oportunidade para desafortunados consultarem "espíritos" em vista da resolução de problemas práticos. A possessão "tende para a histeria", passa a ser apenas um fenômeno de compensação, expressão de frustrações e ressentimentos; não assistimos a um "drama litúrgico", mas à invenção de "deuses que não passam de imagens do Eu" (Bastide, 1971:390ss e 521); a consciência individual perde o suporte e o controle do grupo, e o terreno fica aberto para explorações de todo tipo, inclusive para crimes, cometidos por indivíduos entregues a seus instintos.

Portanto, reencontramos aí vários de nossos temas. A psiquiatrização da experiência do transe, a relação entre uma prática religiosa e atributos moral e socialmente desqualificadores, a possibilidade dessas práticas criarem um ambiente propício ao crime e à "exploração da 
credulidade das classes baixas". Por fim, é seu próprio estatuto religioso que aparece questionado: "A macumba do Rio se desnatura cada vez mais: acaba perdendo todo caráter religioso, para terminar em espetáculos ou se prolongar em pura "magia negra'" (Bastide, 1971: 411). Se por um lado, isso tem a ver com a desagregação social na qual foram apanhados os freqüentadores dessas práticas, tinha a ver também com uma desagregação cultural e religiosa. Pois enquanto no candomblé há um conjunto limitado e estruturado de personalidades míticas,

"o sincretismo e o espiritismo não apenas multiplicam essas personalidades [...], mas ainda apagam os característicos dos deuses, tornando vagos os conceitos, no interior dos quais cada pessoa pode pôr tudo quanto quer." [Bastide, 1971:522]

O trecho acima é interessante por apresentar uma oposição - entre "candomblé" e "espiritismo" - que é retomada em outro texto de Bastide (1967), especificamente sobre o "espiritismo", em que ele propõe uma "psicologia das classes sociais" que comporta basicamente dois argumentos. No primeiro deles, chega-se a uma distinção entre três formas de "espiritismo" de acordo com a interpretação que lhe deram cada uma das classes sociais do Brasil urbano. Primeiro, o "espiritismo-ciência" das classes altas; em seguida, o "espiritismo religioso, organizado em igrejas, repousando sobre a dogmática kardecista" das classes médias e brancas; esse espiritismo kardecista se oporia, por seu moralismo e seu intelectualismo, a uma terceira modalidade, o "espiritismo de Umbanda", uma religião ritualística e não organizada, surgida a partir das condições das classes pobres e negras. Na medida em que essas três formas de "espiritismo" expressariam todas as condições ou exigências de classes sociais, elas se oporiam, como "ideologias", ao candomblé, verdadeira "religião" a partir da qual uma solidariedade social havia se desenvolvido e perpetuado ${ }^{25}$.

A outra dimensão explorada por Bastide neste texto é a natureza do transe. Nesse caso, o "espiritismo de Umbanda" é aproximado do candomblé, na medida em que ambos expressam um conjunto de re- 
presentações míticas que são coletivas - embora de forma menos organizada na "umbanda". Nos rituais "kardecistas", o transe seria apenas parcial, acabando por dramatizar e externalizar os "conflitos interiores da psiquê" do "médium" (1967:14-15). A descrição aproxima-se bastante daquela que vimos a respeito da "macumba", ainda mais se lembrarmos que Bastide identifica, entre o conjunto dos instintos e das pulsões inconscientes, desejos e tendências tipicamente "proletários". A diferença, entretanto, reside em que, no "espiritismo kardecista", esses instintos são sempre vencidos pela ênfase na educação, pelo moralismo e o intelectualismo de sua doutrina.

Notamos, então, a presença de acusações muito semelhantes àquelas mobilizadas pelo discurso médico - curandeirismo, crime e patologia mental -, concentradas agora sobre um espaço bem definido e restrito do espectro religioso: a "macumba urbana". Isso se tornou possível a partir de uma operação de "sociologização" proposta por Bastide. Uma das marcas mais definidoras da "macumba" seria o desenvolvimento de um transe incontrolado, sendo que seu caráter patológico decorria não mais de processos psicológicos relacionados à possessão em geral, mas das condições em que um ritual se realizava. E é muito significativo que, para Bastide, o problemático resida em um excesso das individualidades, na exteriorização de fantasias pessoais, e não, como ocorria entre as teorias psiquiátricas da década de 30, em uma desagregação da personalidade. Ao transe na "macumba" faltava seja a sustentação de um grupo unido por uma solidariedade religiosa (como no "candomblé"), seja o contrapeso de uma doutrina moralista e puritana (como no "kardecismo"). Na ausência dessas condições, a variável que passava a ser determinante era o estatuto social dos indivíduos envolvidos, localizados por Bastide entre as camadas mais desfavorecidas e desagregadas da sociedade brasileira. É como se a "predisposição", nesse caso, não estivesse situada mais na psicologia individual, nem em um "sentimento religioso", mas proporcionada por determinadas condições sociais, às quais correspon- 
deriam certas expressões cosmológicas e rituais. É essa operação de "sociologização" que permite, ao mesmo tempo, a persistência dos temas presentes na discussão sobre o "espiritismo" desde o início do século e o deslocamento em função do qual eram aplicados a uma forma bem específica de "espiritismo".

É em virtude da mesma operação de "sociologização" que o "espiritismo", ou melhor, os "espiritismos" são definidos não exatamente como "religião", e mais propriamente como "ideologia". Bastide propunha, em seus escritos, um argumento que, sob termos na maioria das vezes bem diferentes, seria bastante utilizado por outros pesquisadores que se interessaram contemporânea ou posteriormente pela umbanda e pelo espiritismo kardecista. Para ficar apenas em um exemplo, cito os estudos de Procópio Camargo (1961 e 1973) sobre a umbanda e o kardecismo, cuja preocupação central era apontar qual a "função" que esses cultos assumiam para seus adeptos no contexto de uma sociedade passando por um processo de modernização. Outros trabalhos - como, por exemplo, o de Velho (1975) a respeito da umbanda, e o de Cavalcanti (1983) a respeito do kardecismo - partiram, por outro lado, de uma discordância explícita com esse tipo de perspectiva, preferindo explorar as tensões e categorias específicas a determinados sistemas religiosos, ao invés de se perguntar se e como eles expressam, traduzem ou encenam processos localizados em outro nível de realidade (estrutura social, classes sociais, etc.). Entretanto, convergindo ou não para argumentos sociologizantes, todos esses trabalhos distanciam-se do de Bastide - e, na verdade, de toda uma tradição anterior a ele - quanto ao fato de a definição de "religião" conferida a seus respectivos objetos ser mais ou menos automática, como se decorresse, pelo menos de um ponto de vista acadêmico, de uma auto-evidência. Demonstração do estatuto conquistado pelo "espiritismo" - "religião" com o mesmo valor de outras - e indicação do discurso mais habilitado para dele tratar e teorizar - aquele formulado por sociólogos e antropólogos. 


\section{Considerações finais: espiritismo, higiene mental e civilização}

Procurou-se, nos itens anteriores, localizar os principais momentos em que o "espiritismo" aparece como algo objetificado a partir de categorias e argumentos médicos, muitas vezes encarnados em instituições e agentes sociais com considerável poder de intervenção social. A transformação das categorias mobilizadas e a predominância de alguns argumentos sobre outros serviu tanto para demonstrar as metamorfoses da noção de "espiritismo", quanto para vislumbrar alguns aspectos da organização e aplicação do saber médico. Finalmente, demonstrou-se como certos temas e certas explicações, forjadas no interior desse saber, reaparecem nos posicionamentos de intelectuais que se afastaram da Medicina, como Arthur Ramos, ou que nunca tiveram com ela relações privilegiadas, como Bastide. $\mathrm{O}$ que, aliás, revela uma dimensão deliberadamente subestimada neste artigo: a dos modos de articulação entre discursos medicalizantes e discursos produzidos a partir de outros saberes, científicos, jurídicos, estatais e jornalísticos. Não se esqueça, por fim, daqueles que, ao longo dessa história, assumiram e defenderam o rótulo de "espíritas", posição a partir da qual se situaram seja para afirmar a especificidade e positividade de suas práticas, seja para transformá-las no sentido de torná-las o mais distante possível da imagem que delas faziam os discursos medicalizantes ${ }^{26}$.

O objetivo destas considerações finais é retomar uma questão já apresentada no decorrer do texto - a das relações entre Medicina e Ciências Sociais - a partir da problematização da noção de "higiene mental". O objeto parece ser bastante adequado ao objetivo, na medida em que se trata de uma noção presente nos posicionamentos tanto de Leonídio Ribeiro e Murillo de Campos, quanto de Arthur Ramos, exatamente a propósito de algo - o "espiritismo" - que até então - 
década de 30 - tinha sido tratado a partir dos saberes médicos e passaria, algum tempo depois, à alçada de antropólogos e sociólogos. Digamos logo que a noção de "higiene mental" tinha uma aplicação muito abrangente e fora introduzida no meio médico no final da década de 1910, ganhando, em pouco tempo, vários adeptos e propulsores. Chegou a constar da denominação de uma das principais entidades de psiquiatras dos anos 20 e 30, a Liga Brasileira de Higiene Mental. A Liga foi a responsável pela consagração do significado atribuído à "higiene mental" - a "profilaxia das doenças mentais" - e o pivô das teorizações e aplicações sociais justificadas em seu nome. Entre elas, constam a constituição de serviços junto a várias instituições, reivindicações de mudanças legislativas e a execução de reformas no sistema público de educação (Costa, 1980 e Correa, 1982).

Apesar de sua importância, a noção de "higiene mental" tem ocupado até agora um lugar bastante marginal entre os trabalhos dedicados a discutir "saúde pública" no Brasil (Iyda, 1994; Luz, 1982; Costa, 1983). Algo curioso, considerando que o período desde a passagem do século até a década de 30 é exatamente tido como privilegiado nessas discussões. Privilegiado, primeiro, porque é nele que se consolida e se cristaliza em várias instituições o saber médico que os países centrais elegeram como o mais "científico" (associado aos progressos da parasitologia, da bacterologia e da imunologia); em seguida, porque está marcado por uma crescente centralização, fortalecimento e expansão das instituições responsáveis pela administração dos serviços de saúde. Juntos, esses fatores faziam da "saúde pública" uma das principais armas para o fortalecimento do Estado e a disciplina das populações. Na literatura existente, os argumentos concentram-se, especialmente, na relação entre esses processos e a problemática do desenvolvimento e das vicissitudes do capitalismo no Brasil ${ }^{27}$. O fim da escravidão e os primórdios da industrialização - com suas consequiências sociais - teriam produzido certas exigências quanto a uma 
nova estratificação do espaço urbano e às condições para a acumulação do capital. Nesse contexto, coube à Medicina o papel de "higienizar" a cidade brasileira, cerrando esforços no sentido de combater as doenças que manchavam a imagem nacional no exterior e dizimavam parte considerável da mão-de-obra. Cumprindo com sucesso seu papel, a medicina social das primeiras décadas o faria através de um constante desprezo pelas causas efetivas da insalubridade das camadas mais desfavorecidas da população, relacionadas com as conseqüências do mesmo capitalismo para o qual o médico teria sido quase um intelectual orgânico.

Uma das situações sempre evocadas para reafirmar argumentos dessa natureza são as campanhas sanitárias idealizadas e conduzidas por Oswaldo Cruz, entre 1903 e 1904, no Rio de Janeiro - as primeiras de uma série de outras que se desenvolveriam no decorrer das décadas seguintes em meios urbanos e rurais. $\mathrm{O}$ combate a doenças epidêmicas foi acompanhado, além do mais, pela reforma do porto e por extensas obras de remodelação urbana que alteraram toda a topografia e a arquitetura da zona central, sendo que boa parte das reformulações foi justificada a partir de um discurso médico preocupado com a higiene da cidade e a saúde da população. O resultado, segundo vários autores (Costa, 1983; Benchimol, 1990; Sevcenko, 1984), teria sido a efetivação de uma nova e mais eficiente rede de circulação de mercadorias e trabalhadores e a produção de uma nova estratificação espacial, segregando as camadas mais pobres, que adaptaram a cidade aos imperativos colocados pela situação do Brasil no concerto das nações, e pelas necessidades de movimentar as engrenagens econômicas, políticas e sociais que suportavam a República.

O problema dessa descrição é que pode induzir a uma simplificação da situação, pois dá margem à afirmação de que o discurso da "higiene pública" tivesse sido utilizado simplesmente para se atingir a objetivos ou necessidades de ordem econômica e social. É nesse sentido que o argumento pode se tornar reducionista, deixando de 
contemplar como parte do diagnóstico da situação da cidade pelo menos outras duas dimensões. Primeiro, a "remodelação" havia sido concebida também como um "embelezamento", trazendo em seu bojo o compromisso com determinadas concepções estéticas presentes na construção de prédios e na distribuição dos espaços. Segundo, havia na intervenção estatal uma dimensão propriamente "civilizacional", expressa em um conjunto de regulamentações aplicado a várias atividades econômicas e culturais: desde a proibição de venda de miúdos em tabuleiros e da ordenha de vacas nas ruas, passando pela repressão à mendicidade pública e a hostilidade aos ambulantes, até a normatização de várias diversões populares (como o entrudo, o carnaval e as serenatas). Os regulamentos sanitários, que estabeleciam as circunstâncias que cercavam o combate às epidemias, também traziam diversos dispositivos da mesma natureza. Ou seja, mais do que simplesmente dar outra conformação espacial e social ao Rio de Janeiro, importava torná-lo uma cidade "civilizada" em suas paisagens e seus costumes. E reivindicações nesse sentido podiam ser ouvidas partindo de políticos, governantes e "homens de sciencia" e apareciam nitidamente na crônica de um Luís Edmundo ou na reportagem de um João do Rio.

Parece que estamos distantes da discussão anteriormente levantada. Ao contrário, é exatamente a partir dessas últimas observações que se pode refazer o vínculo entre as noções de "higiene mental" e "higiene pública", vínculo perdido para os autores que se debruçaram sobre a segunda delas. Pois há, da primeira com respeito à segunda, uma relação ao mesmo tempo de analogia e de continuidade. Por um lado, ao pretender a "profilaxia das doenças mentais", a "higiene mental" constituía um espaço distinto de intervenção médica, que investe não sobre as doenças que degradam fisicamente os indivíduos (atribuição reservada aos sanitaristas e epidemiólogos), mas sobre os fatores de degradação mental. Por outro, trata-se de dar prosseguimento, em outro nível, e de levar a termo a "ação civilizatória" que a "higiene pública" prometera, através 
de intervenções físicas, arquitetônicas e humanas, realizar nas cidades. Em outras palavras, tratava-se de, pela eleição do "mental" como campo de intervenção, cumprir com maior radicalidade a missão a que se tinha proposto a Medicina em relação à população ${ }^{28}$.

Não tendo sido objeto da preocupação de autores que trataram das políticas de "saúde pública", a "higiene mental" vem aparecer como tal em textos dedicados à história da Psiquiatria e da Medicina Legal no Brasil. É o caso do trabalho de Jurandir Freire Costa (1980) sobre o ideário e a atuação da Liga Brasileira de Higiene Mental, cujo aspecto mais destacado é a formulação de propostas de intervenção social moldadas nas teorias então em voga na Psiquiatria da Alemanha pré-nazista. Sugere-se que a ação da Liga deva ser interpretada como o apogeu de uma lógica biologicista aplicada aos problemas sociais, o que respaldava, por exemplo, reivindicações de teor eugênico (como a realização de exames pré-nupciais para evitar o casamento entre "degenerados" e o controle da imigração). Diante disso, as observações de Mariza Correa (1982) a respeito da noção de "higiene mental" constituem um interessante contraponto. Elas se fazem a propósito das teorizações e da atuação de Arthur Ramos no campo da pedagogia infantil e o ponto mais ressaltado é exatamente a divergência em relação a posições e argumentos estritamente biologicistas. Os problemas das crianças observadas por Arthur Ramos tinham origem, segundo ele, em um "determinismo afetivo" que remetia para sua situação familiar. Haveria então, sugere Correa, várias diferenças entre intervenções caucionadas pela noção de "higiene mental" e as medidas que partiam de pessoas vinculadas à Medicina Legal, como era o caso de Leonídio Ribeiro, diferenças que podiam ser resumidas na oposição entre trabalho pedagógico e políticas repressivas. O par, entretanto, constituiria menos uma antinomia e mais uma complementaridade, já que as respectivas intervenções desenvolviam, a serviço de uma mesma tarefa, competências distintas: a "higiene mental" agindo sobre indivíduos "normais", em ambientes "abertos", buscan- 
do preventivamente o seu "ajuste" à sociedade; as técnicas desenvolvidas sob a égide da Medicina Legal atuando sobre "desviantes", em "instituições totais", produzindo a segregação dos indivíduos.

Agora já podemos retomar a discussão a respeito do "espiritismo", vendo como a forma com a qual aí aparece a noção de "higiene mental" pode colaborar para avançarmos na sua compreensão. O ponto a ser mais enfatizado é o levantado por Mariza Correa a respeito da crítica a argumentos estritamente biologicistas contida na idéia de "higiene mental", ponto que acaba obscurecido pela sua associação com uma atuação "pedagógica" em oposição a uma "repressiva". Pois o que se pode depreender dos posicionamentos médicos tomados na década de 30 a respeito do "espiritismo" é que a "higiene mental" servia para ancorar tanto medidas pedagógicas - como aquelas sugeridas por Arthur Ramos - quanto medidas repressivas - como aquelas reivindicadas pela campanha proposta por Leonídio Ribeiro e subscrita por vários psiquiatras e médicos-legistas. Mais do que isso, ambas as medidas conviviam em uma mesma reivindicação, caso da campanha levantada por Leonídio Ribeiro, preocupada ao mesmo tempo em fechar centros espíritas e aprisionar seus mantenedores e em prestar esclarecimentos e cuidados médicos ao público das sessões. Isso significa que a especificidade da noção de "higiene mental" não estava necessariamente no tipo de intervenção por ela justificada.

Em que essa especificidade residiria então? Na natureza dos fatores considerados para a formulação do que, na linguagem médica, sempre equivalia a um diagnóstico. Se isto for correto, a noção de "higiene mental" designaria teorizações - e propostas de intervenção social nelas fundamentadas - em que coisas como "hábitos" e "crenças" ocupam um lugar tão básico quanto as noções de "raça" e de "degeneração mental". Isso fica bem evidente nas posições de Arthur Ramos diante do problema do "curandeirismo" - reflexo de uma psicologia específica permeada de "superstição" e "misticismo" - e decorre diretamente de seu esforço em substituir a categoria de "raça" 
pela de "cultura" para pensar a "questão do Negro". Mas está também presente nas posições menos condescendentes de um Leonídio Ribeiro e se explicita no argumento de que muitas vezes uma "mediunomania", embora sempre dependa de uma "predisposição" que marca constitucionalmente o indivíduo atingido, só se desenvolve depois do contato com os fenômenos e bizarrias de uma sessão de "espiritismo" - algo, lembremos, que designava um conjunto de idéias disparatadas próprias às "primeiras fases do espírito humano". Para ambos, o "espiritismo" florescia em meios e ambientes nos quais reinavam formas "atrasadas", "involuídas", "primitivas" de pensamento, em populações cujas "crenças" e "hábitos" se situavam no limiar entre a ignorância e a patologia.

Isso nos coloca novamente diante do problema da "civilização", da sua restrição a alguns poucos "bolsões de racionalidade" e da necessidade ou possibilidade de seu avanço sobre a maioria da população. E seria fácil demonstrar como esse problema tinha, na verdade, adquirido uma repercussão muito mais geral e constava da agenda de discussões entre a intelectualidade brasileira desde pelo menos as últimas décadas do século XIX (Schwarcz, 1993; Borges, 1993). Tratava-se de um tema para o qual convergiam, por exemplo, as preocupações de um cientista como Nina Rodrigues, de um literato como Euclides da Cunha e de vários escritores naturalistas do final do século. Uma das questões que mais os incomodava dizia respeito exatamente à viabilidade do Brasil como nação, problemática especialmente em virtude da coexistência de múltiplos grupos raciais. Dúvida que se manterá nas décadas de 20 e 30, em torno das recorrentes teorizações sobre o "caráter" e a "psicologia" nacionais. Recebendo respostas mais otimistas ou mais pessimistas, tal debate mobilizou segmentos consideráveis de nossa intelectualidade e as obras de Monteiro Lobato, Paulo Prado e Gilberto Freyre não podem ser entendidas sem que nos remetamos a essas discussões. Lembremos ainda que delas faziam parte 
toda a primeira geração de modernistas, com seu elogio do "primitivismo mulato", e os ideólogos do Estado Novo. Agora, os argumentos não giravam apenas em torno da diversidade racial, mas abrigavam também considerações sobre nosso passado colonial, os costumes rurais e as crenças "supersticiosas" de uma boa parte da população.

A "higiene mental" - é o que se está sugerindo aqui - designava um conjunto de formulações e atuações que representavam o modo de intervenção de uma parcela da classe médica nesse debate mais amplo, no qual se tematizava o "caráter" e a "viabilidade" de uma nação. Isso está explicitamente reconhecido, por exemplo, no momento em que Arthur Ramos (1940:353) considera as religiões negras como via de acesso para a "psiquê coletiva do brasileiro", mas aparece, de forma menos clara, também na condenação de Afrânio Peixoto ao "espiritismo", prova da existência de "erros que vem de longe, impregnados como estão no sangue do nosso povo" (apud Ribeiro e Campos, 1931:9). Contudo, o ponto mais importante a respeito da "higiene mental" reside na redefinição do estatuto de fenômenos como o "espiritismo", proporcionada exatamente pela forma com que esses argumentos se introduziam no debate, ou seja, enfatizando a fundamentalidade de fatores como "crenças" e "hábitos".

Acompanhar o modo como o "espiritismo" foi tratado pelo discurso médico demonstra que a "higiene mental" se constituiu ao mesmo tempo na última e mais específica forma de intervenção medicalizante e no pioneiro tratamento baseado em uma perspectiva culturalista. As articulações entre essas formas eram complexas e tensas, mas a prova de que as tendências se inclinavam para a segunda delas está no fato de que, à medida que se aproximam as décadas de 40 e 50, os médicos vão se sentir cada vez menos à vontade e vão ser cada vez menos convidados a se pronunciar sobre "crenças" e "hábitos", rótulos que então designavam coisas até bem pouco tempo atrás sob sua alçada de análise e intervenção. Isso acontece em virtude não de uma inocente 
perda de interesse dos médicos por esses assuntos - condições e categorias para se falar deles existem ainda hoje $\mathrm{e}^{29}$ - mas da transformação de seu estatuto em direção a definições que desautorizavam a competência médica em benefício de outras, especialmente a de cientistas sociais. Daí a razão para que o "espiritismo" passe a estar investido do estatuto de "religião" - e "religião" entre outras "religiões" e que práticas anteriormente constituídas em alvo de ataques e polêmicas - mediunidade, possessão, todas as formas terapêuticas - passem a ser abordadas por referência exatamente a essa totalidade designada por concepções e visões "religiosas". Em contrapartida, a presença, como vimos, de argumentos psiquiatrizantes na obra de um dos mais clássicos desses cientistas sociais constitui prova ao mesmo tempo de sua força e da possibilidade de sua subordinação e realocação em função de variáveis (sociológicas, no caso de Bastide) tornadas mais fundamentais.

Os significados atribuídos à categoria "higiene mental" e os modos como foi utilizada podem ser tratados, então, enquanto indicativos de uma passagem, historicamente localizável, do biológico para o cultural em uma certa vertente do pensamento social brasileiro. Como observação final, vale sugerir que essa passagem seja compreendida não como o rompimento com um passado, mas enquanto um dos marcos da formulação de um problema que foi legado às ciências sociais e que continua atual em nossas discussões: o da diversidade de crenças e de culturas que conforma a nação brasileira. Reconhecido isto, há inclusive a possibilidade de traçarmos analogias entre a situação que acompanhamos no Brasil e o que aconteceu com a sociologia durkheimiana na França ou com a antropologia funcionalista e estrutural-funcionalista na Inglaterra. Cada uma dessas tradições disciplinares, em seus processos de constituição, preserva e recoloca em outros termos problemas que lhes eram anteriores: respectivamente, a conservação da ordem social, pedra de toque de várias correntes do pensamento social 
francês, e a política colonial, empreendimento que manteve por muito tempo antropólogos e administradores ligados uns aos outros. Com todas as especificidades que lhe são inerentes, o pensamento social brasileiro esteve às voltas com esse mesmo movimento de compromisso e ruptura com um problema crucial e seria possível relacionar uma verdadeira linhagem de pensadores, com suas ramificações e conflitos de parentesco, dedicados a refletir sobre o problema da nação a partir do dado de sua diversidade cultural. Demonstrar e comentar essas reflexões constituiu-se na preocupação de um número igualmente extenso de estudiosos. Reconhecendo isto, a pretensão deste texto consistiu em revelar de que modo o espiritismo esteve envolvido com esses problemas cruciais.

\section{Notas}

1 Sobre o espiritismo considerado dentro da acepção que lhes conferem os kardecistas, pode-se consultar, tanto para informações sobre sua introdução e consolidação no Brasil, quanto para apresentações de suas cosmologias, práticas e instituições, os seguintes trabalhos: Aubrée e Laplantine (1990), Cavalcanti (1983), Damazio (1994), Hess (1987b) e Giumbelli (no prelo).

2 Há uma vasta literatura a respeito da umbanda. Restrinjo-me a algumas referências: Ortiz (1978), Montero (1983), Brown (1974) e ISER (1985). Sobre o Racionalismo Cristão, ver Maggie (1992) e Gama (1992).

3 Sobre práticas terapêuticas associadas ao espiritismo kardecista, pode-se consultar Greenfield (1992), Hess (1987a) e Warren (1984). No caso da umbanda, ver Montero (1983).

4 A questão é tratada com mais vagar no trabalho de Machado et al (1978).

5 Sobre a história da homeopatia no Brasil, aliás em muitos de seus aspectos associada à do espiritismo, ver Warren (1984) e Luz (1986). 
6 Benoît Mure será acusado de ter cometido alguns crimes e os homeopatas em geral eram criticados por se utilizarem de meios irrecomendados (como reclames em jornais) para propagarem suas idéias (Luz, 1986).

7 Os trabalhos de Maggie (1992) e Schritzmeyer (1994) enfocam exatamente a dimensão jurídica do combate ao "curandeirismo", um tema que também ocupa lugar fundamental em minha pesquisa (Giumbelli, no prelo).

8 Especificamente sobre os conceitos, visão de mundo, contexto intelectual e personagens da "psicologia fisiológica", ver Barberis (1992). Várias de suas formulações estavam bastante informadas pelo que Duarte (1986) chamou de "configuração do nervoso" e os seus diversos temas.

9 Francisco Fajardo era, na época da edição de seu livro, professor assistente da cadeira de Clínica Propedêutica na Faculdade de Medicina e também chefe do Laboratório Bacteriológico Federal.

10 Para uma visão abrangente da obra e da carreira de Nina Rodrigues, a referência indispensável continua sendo o trabalho de Correa (1982).

11 O ponto já aparecia em um texto de 1890, apresentado por Nina Rodrigues no III Congresso de Medicina e Cirurgia. Trata-se de "A Abasia Choreiforme Epidemica no Norte do Brasil”, publicado em Nina Rodrigues (1939).

12 Sobre a trajetória da Psiquiatria no século XIX e os dilemas que gerou, ver Carrara (1988).

13 O texto em questão é “A Loucura das Multidões", originalmente publicado em 1901 e depois compilado em Nina Rodrigues (1939).

14 Os textos em que o médico baiano enfrenta diretamente as questões da proibição e da repressão legais ao curandeirismo são Nina Rodrigues (1899 e 1945).

15 O "inquérito" foi promovido por iniciativa do médico-legista Leonídio Ribeiro e acabou sendo publicado no jornal $A$ Noite. Dele participaram os 
professores da Faculdade de Medicina do Rio de Janeiro A. Austragésilo (neurologia), Henrique Roxo (clínica psiquiátrica), Espozel (clínica psiquiátrica e neurológica), Tanner de Abreu (medicina legal), Júlio Porto Carreiro (medicina pública), Raul Leitão da Cunha (anatomia patológica) e Pedro Pernambucano Filho (psiquiatria); os professores de medicina pública nas Faculdades de Direito, João Fróes (Bahia) e Carlos Seidl (Rio de Janeiro); Franco da Rocha e Pacheco e Silva, diretores em períodos diversos do Hospício Juquery de São Paulo. O único que não era médico e respondeu ao inquérito foi Everardo Backeuser, professor na Escola Politécnica do Rio de Janeiro. As respostas estão transcritas em Ribeiro e Campos (1931).

16 Em meu trabalho (Giumbelli, no prelo) procuro esclarecer quais os fatores que produziram a vitória dos argumentos psiquiatrizantes quanto à explicação dos fenômenos associados ao espiritismo. Chamo atenção tanto para a inserção institucional daqueles que postulavam, no rastro de Nina Rodrigues, tais argumentos, como para a desconfiança, nos meios médi$\cos$, a respeito das pretensões terapêuticas generalizadas de sistemas, como o de Fajardo, baseados na "sugestão".

17 Sobre a institucionalização da Psiquiatria e da Medicina Legal no Brasil, podese consultar, entre outros, Carrara (1988), Correa (1982) e Costa (1980).

18 Segundo as indicações que pude reunir, o "espiritismo" era um problema cuja interpretação congregava esforços de várias tendências do pensamento médico europeu do início do século. No caso da França, ganharam maior expressão as obras de Charles Richet e de Marcel Violet, o primeiro propondo um novo conjunto de hipóteses ("metapsíquica") para dar conta dos fenômenos ditos "espíritas" de modo a fazê-lo um precursor da Parapsicologia; o segundo traçando associações entre "espiritismo" e "loucura".

19 Ver Gama (1992), cujo tema é justamente os embates entre espíritas e médicos entre as décadas de 10 e 30 .

20 Para as posições de Henrique Roxo, um dos mais importantes psiquiatras brasileiros da primeira metade do século, ver Roxo (1926) e (1946). Já as posições de Xavier de Oliveira estão expostas em um livro (Xavier de Oliveira, 1931). 
21 Esta imagem que desvenda as "formas elementares" de uma sessão espírita também é encontrada nos textos de Xavier de Oliveira (1931:225) e de Roxo (1946). Cito a descrição deste último: "Muitas pessoas se reúnem em uma sala pequena. $\mathrm{O}$ médium fica no meio. $\mathrm{O}$ chefe fica ao lado do médium. Aquele sugestiona este e lhe diz que invoque um espírito conhecido. O medium se põe a tremer, solta grandes gritos, agita-se muito. [...] As sessões finalizam quase sempre com crises de nervos e um estado geral de excitação mais ou menos intenso" (:468-9). A descrição prossegue contando como um indivíduo mais impressionável passa, já terminada a sessão, a ser acometido por alucinações.

22 Sobre a obra de Arthur Ramos, pode-se consultar Correa (1982); Dantas (1988) e Birman (1985).

23 Foi imbuído dessas propostas que Arthur Ramos assumiu as funções de diretor do Serviço de Ortofrenia e Hygiene Mental nas escolas públicas do Rio de Janeiro durante a década de 30, desenvolvendo atividades pedagógicas sobre alunos, pais e professores. No mesmo período, Ulysses Pernambucano, psiquiatra, orientava seus esforços intelectuais e políticos frente aos cultos africanos de Recife em torno da mesma noção de "higiene mental", servindo de mediador entre pais de santo e autoridades policiais. Ver Correa (1982) e Dantas (1988).

24 Ver também Carneiro (1981), que faz observações bem semelhantes quando analisa os "candomblés de caboclo" de Salvador, recorrendo também à categoria "baixo espiritismo". Trata-se de uma expressão amplamente utilizada a partir da segunda metade da década de 1920, não só por intelectuais, mas especialmente por jornalistas e agentes oficiais da repressão à prática ilegal da medicina, cujo surgimento e disseminação foram objeto de várias observações em meu trabalho (Giumbelli, no prelo).

25 Veja-se as "Conclusões" de As religiões africanas no Brasil (Bastide, 1973), especialmente o item "Religião e Ideologia".

26 Estas duas dimensões, sobre a articulação entre os diversos discursos tecidos a respeito do "espiritismo" e sobre as respostas formuladas por uma determinada instituição identificada com o espiritismo kardecista, constituem-se nos objetivos básicos de meu trabalho (Giumbelli, no prelo). 
27 São exemplos dessa perspectiva, aqui descrita evidentemente apenas em seus traços mais gerais, os trabalhos de Luz (1982) e de Costa (1983).

28 Sobre os projetos nacionais associados à ação e ao ideário das corporações médicas, veja-se o trabalho de Schwarcz (1993).

29 Um exemplo da intervenção do saber psiquiátrico em um caso recente de crime envolvendo adeptos de cultos mediúnicos é oferecido pelos trabalhos de Contins (1983), Contins e Goldman (1985) e Maggie (1992).

\section{Bibliografia}

AUBRÉE, M. e LAPLANTINE, F.

1990 La table, le livre et les esprits, Paris, J.C.Lattès.

BARBERIS, D.

1992 Indivíduo e personalidade na psicologia fisiológica francesa do final do século XIX, dissertação de Mestrado, Rio de Janeiro, PPGAS/MN/UFRJ.

BASTIDE, R.

1967 “Le spiritisme au Brésil”, in Archives de Sociologie des Religions, n 24.

1971 [1960] As religiões africanas no Brasil, São Paulo, Pioneira.

1973 Estudos afro-brasileiros, São Paulo, Perspectiva.

BENCHIMOL, J.L.

1990 Pereira Passos: um Hausmann tropical. A renovação urbana da cidade do Rio no início do século XX, Rio de Janeiro, Sec. Mun. de Cultura, Turismo e Esportes.

BIRMAN, P.

1985 "Registrado em cartório, com firma reconhecida: a mediação política das federações de Umbanda", Umbanda e Política, Cadernos do ISER, $\mathrm{n}^{\circ}$ 18, Rio de Janeiro, Marco Zero/ISER. 
EMerson Giumbelli. Heresia, doEnÇA, CRIME OU RELIGĩ̃o

BORGES, D.

1993 "Degeneration in Brazilian Social Thought, 1880-1940", Journal of Latin American Studies, $\mathrm{n}^{\mathrm{o}} 25$.

BROWN, D.

1974 Umbanda: politics of an urban religious movement, tese de doutorado.

CAMARGO, C.P.

1961 Kardecismo e Umbanda, São Paulo, Pioneira.

1973 Católicos, protestantes e espíritas, Petrópolis, Vozes.

CARNEIRO, E.

1981 [1937] Negros bantos. Notas de etnografia religiosa e de folclore, Rio de Janeiro, Civilização Brasileira.

CARRARA, S.

1988 Crime e loucura: o aparecimento do Manicômio Judiciário na passagem do século, Rio de Janeiro, dissertação de Mestrado, PPGAS/MN/UFRJ.

CAVALCANTI, M.L.

1983 O mundo invisível. Cosmologia, sistema ritual e noção de pessoa no Espiritismo, Rio de Janeiro, Zahar.

CONTINS, M.

1983 O caso da pomba-gira: reflexões sobre crime, possessão e imagem feminina, Rio de Janeiro, dissertação de Mestrado, PPGAS/MN/UFRJ.

CONTINS, M. e GOLDMAN, M.

1985 “'O caso da Pomba-Gira’: religião e violência. Uma análise do jogo discursivo entre Umbanda e sociedade", Religião e Sociedade, $\mathrm{n}^{\circ}$ 11/1.

CORREA, M.

1982 As ilusões da liberdade. A Escola Nina Rodrigues e a Antropologia no Brasil, São Paulo, Tese de Doutorado, FFLCH/USP. 
Revista de Antropologia, São Paulo, USP, 1997, v. 40 nº2.

COSTA, J.F.

1980 História da psiquiatria no Brasil, Rio de Janeiro, Campus.

COSTA, $\mathrm{N}$.

1983 Estado e políticas de saúde pública (1889-1930), Rio de Janeiro, dissertação de Mestrado, IUPERJ.

DAMAZIO, S.F.

1994 Da elite ao povo: advento e expansão do Espiritismo no Rio de Janeiro, Rio de Janeiro, Bertrand.

DANTAS, B.G.

1988 Vovô nagô e papai branco - usos e abusos da África no Brasil, Rio de Janeiro, Graal.

DUARTE, L.F.D.

1986 "Uma inquirição histórica sobre a perturbação moderna", Da vida nervosa das classes trabalhadoras urbanas, Rio de Janeiro, Zahar/CNPq.

FAJARDO, F.

1896 Tratado de Hypnotismo, Rio de Janeiro.

GAMA, C.P.

1992 O espírito da Medicina - médicos e espíritas em conflito, Rio de Janeiro, dissertação de Mestrado, IFCS/UFRJ.

GIUMBELLI, E.

no prelo $O$ cuidados dos mortos: acusação e legitimação do espiritismo, Rio de Janeiro, Arquivo Nacional.

GREENFIELD, S.

1992 "O corpo como uma casca descartável: as cirurgias do Dr. Fritz e o futuro das curas espirituais", Religião e Sociedade, n 16/1-2. 
EMerson Giumbelli. Heresia, doEnÇA, CRIME OU RELIGĩ̃o

HESS, D.

1987a Spirits and science in Brazil: an anthropological interpretation of religion and ideology, tese de Doutorado, Cornell University.

1987b "The many rooms of Spiritism in Brazil”, Luso-Brazilian Review, XXIV, 2.

ISER

1985 Cadernos do ISER - Umbanda e Política, Rio de Janeiro, Marco Zero/ISER.

IYDA, M.

1994 Cem anos de saúde pública. A cidadania negada, São Paulo, UNESP.

LUZ, M.

1982 Medicina e ordem política brasileira: políticas e instituições de saúde (1850-1930), Rio de Janeiro, Graal.

1986 "História político institucional da homeopatia no Brasil: a implantação (1840-1859)", Textos para Discussão, UFRJ, IFCS, nº6.

MACHADO, R.; LOUREIRO, A.; LUZ, R. e MURICY, K.

1978 Danação da norma. Medicina social e a constituição da psiquiatria no Brasil, Rio de Janeiro, Graal.

MAGGIE, Y.

1992 Medo do feitiço: relações entre magia e poder no Brasil, Rio de Janeiro, Arquivo Nacional.

MONTERO, P.

1983 Da doença à desordem: as práticas mágico-terapêuticas na Umbanda, São Paulo, tese de Doutorado, FFLCH/USP.

MOREIRA, N.J.

1862 Rápidas considerações sobre o maravilhoso, o charlatanismo e o exercício ilegal da medicina e da pharmácia, Rio de Janeiro, Typ. de M.Barreto, Mendes Campos \& Cia. 


\section{NINA RODRIGUES, R.}

1899 "Liberdade profissional em medicina”, Revista Médica de São Paulo.

1935 [1896] O animismo fetichista dos negros da Bahia, Rio de Janeiro, Civ. Brasileira.

1939 [1890 - 1901] Collectividades anormaes, Rio de Janeiro, Civ. Brasileira.

1945 [1905] "Sobrevivências religiosas", Os africanos no Brasil, São Paulo, Cia. Editora Nacional.

ORTIZ, R.

1978 A morte branca do feiticeiro negro, Petropólis, Vozes.

RAMOS, A.

1931 "O problema psychologico do curandeirismo. Trabalho apresentado no $1^{\circ}$ Congresso Médico Sindicalista", Brasil Médico, no 42.

1940 [1934] O negro brasileiro, Rio de Janeiro, Civilização Brasileira.

1946 [1937] As culturas negras no novo mundo, São Paulo, Cia. Editora Nacional.

RIBEIRO, L. e CAMPOS, M.

1931 O espiritismo no Brasil, São Paulo, Cia. Editora Nacional.

ROXO, H.

1926 "Delírio episodico dos degenerados", Brazil-Médico, XL, vol.1, n 19.

1946 [1938] "Delirio espirita episódico", Manual de Psiquiatria, Rio de Janeiro, Guanabara.

SAID, E.

1990 Orientalismo: o Oriente como invenção do Ocidente, São Paulo, Companhia das Letras.

SCHRITZMEYER, A.L.

1994 Sortilégio de saberes. Curandeiros e juízes nos tribunais brasileiros, São Paulo, dissertação de Mestrado, PPGAS/FFLCH/USP. 
SCHWARCZ, L.M.

1993 O espetáculo das raças. Cientistas, instituições e questão racial no Brasil (1870-1930), São Paulo, Companhia das Letras.

SEVCENKO, N.

1984 A Revolta da Vacina. Mentes insanas em corpos rebeldes, São Paulo, Brasiliense.

VELHO, Y.

1975 Guerra de Orixá. Um estudo de ritual e conflito, Rio de Janeiro, Zahar.

WARREN Jr., D.

1984 “A terapia espírita no Rio de Janeiro de Janeiro por volta de 1900”, Religião e Sociedade, $\mathrm{n}^{\circ}$ 11/3.

1986 “A medicina espiritualizada: a homeopatia no Brasil do séc. XIX”, Religião e Sociedade, $\mathrm{n}^{\mathrm{o}}$ 13/1.

XAVIER DE OLIVEIRA.

1931 Espiritismo e loucura, contribuição ao estudo do factor religioso em psychiatria, Rio de Janeiro, A Coelho Branco Filho Editor.

ABSTRACT: From middle of 19th century until the 1940s, spiritists practices and doctrines mobilized medical thought through the dual projects of intellectual engagement and social intervention. This article examines texts written by physicians during this period (such as Nina Rodrigues and Leonidio Ribeiro), and explores the ways in which they define and analyse spiritism. The author's analysis identifies continuities and ruptures over the course of this historical period. In the 1930s, spiritism and possession cults in general served as key references for anthropological and sociological categories, signaling an important transformation in their status (Arthur Ramos is a key name). The author examines this process via an analysis of "mental hygiene", a category used by intelectuals in the 1920s and 1930s and closely linked to debates about the formation and fate of the Brazilian nation.

KEY WORDS: medicine, spiritism, religion, Brazilian social thought.

Aceito para publicação em maio de 1997. 